\title{
Ochratoxin A Producing Fungi, Biosynthetic Pathway and Regulatory Mechanisms
}

\author{
Yan Wang ${ }^{1,2, \dagger}$, Liuqing Wang ${ }^{1,+}$, Fei Liu ${ }^{1}$, Qi Wang ${ }^{1}$, Jonathan Nimal Selvaraj ${ }^{1}$, Fuguo Xing ${ }^{1,2}$, \\ Yueju Zhao ${ }^{1,2}$ and Yang Liu ${ }^{1,2, *}$ \\ 1 Institute of Food Science and Technology, Chinese Academy of Agricultural Sciences, 1 Nongda South Road, \\ Xibeiwang Town, Haidian District, Beijing 100193, China; wangyan062006@163.com (Y.W.); \\ wanglq20082009@163.com (L.W.); liufei0823@yeah.net (F.L.); juwubawangqi@163.com (Q.W.); \\ sjonnim@gmail.com (J.N.S.); fgxing@163.com (F.X.); zhaoyueju@caas.cn (Y.Z.) \\ 2 Key Laboratory of Agro-products Processing, Ministry of Agriculture, 1 Nongda South Road, \\ Xibeiwang Town, Haidian District, Beijing 100193, China \\ * Correspondence: liuyang01@caas.cn; Tel./Fax: +86-10-6281-5874 \\ + These authors contributed equally to this work.
}

Academic Editor: Richard A. Manderville

Received: 1 February 2016; Accepted: 14 March 2016; Published: 21 March 2016

\begin{abstract}
Ochratoxin A (OTA), mainly produced by Aspergillus and Penicillum species, is one of the most important mycotoxin contaminants in agricultural products. It is detrimental to human health because of its nephrotoxicity, hepatotoxicity, carcinogenicity, teratogenicity, and immunosuppression. OTA structurally consists of adihydrocoumarin moiety linked with L-phenylalanine via an amide bond. OTA biosynthesis has been putatively hypothesized, although several contradictions exist on some processes of the biosynthetic pathway. We discuss recent information on molecular studies of OTA biosynthesis despite insufficient genetic background in detail. Accordingly, genetic regulation has also been explored with regard to the interaction between the regulators and the environmental factors. In this review, we focus on three aspects of OTA: OTA-producing strains, OTA biosynthetic pathway and the regulation mechanisms of OTA production. This can pave the way to assist in protecting food and feed from OTA contamination by understanding OTA biosynthetic pathway and regulatory mechanisms.
\end{abstract}

Keywords: ochratoxin A; producing fungi; biosynthetic pathway; regulatory mechanisms

\section{Ochratoxin A}

Ochratoxin A (OTA) was first isolated as a secondary metabolite from Aspergillus ochraceus in 1965 [1]. OTA was identified as a toxic metabolite and considered one of the most important mycotoxins. OTA has a significant economic impact on food commodities in that OTA producing fungi were found to be a contaminant in a wide variety of foodstuffs. OTA is mainly produced by some Aspergillus and Penicillium species. On analyzing OTA structure, it is found as a polyketide-derived secondary metabolite and contains a dihydrocoumarin moiety coupled to an L- $\beta$-phenylalanine (Phe), derived from the shikimic acid pathway, by an amide bond. Its chemical name is: L-phenylalanine- $N$-[(5-chloro-3,4-dihydro-8-hydroxy-3-methyl-1-oxo-1H-2-benzopyrane-7-yl) carbonyl]-(R)-isocoumarin [2].

OTA is a potent nephrotoxic mycotoxin in nature and also displays other adverse effects such as hepatotoxicity, teratogenicity, and immunosuppression [3]. OTA has been proven to be carcinogenic in kidney and liver [4]. It has been classified as a group 2B human carcinogen by the International Agency for Research on Cancer (IARC), and World Health Organization (WHO) [5]. OTA has been putatively implicated in the etiology of Balkan endemic nephropathy (BEN) and recognized to be 
related to urinary-tract tumors [4]. Because of the hazard posed by this mycotoxin, the amount of OTA permitted in food is regulated by European Union and Codex [6].

Here, the OTA producing fungi, its biosynthetic pathway, and its regulation mechanisms will be summarized. All these aspects contribute to understanding OTA biosynthesis and regulation. This assists in realizing the correlation between environmental factors and OTA production and protecting food and feed from the fungal contamination and OTA production.

\section{Ochratoxin A Producing Fungi}

OTA is mainly produced by some species in Aspergillus and Penicillium. OTA presence in various food commodities such as cereals, beans, spices, dried fruits, nuts and oilseeds has been widely reported around the world. In recent years, several studies reported the production of OTA by other fungal species, especially in Aspergillus and Penicillium species (Table 1). They contaminate different crops with a different distribution depending on climatic conditions. Aspergillus species predominate in warm and temperate regions while Penicillium isolates are frequent in colder areas [7]. OTA production is higher at $0.98 a_{\mathrm{w}}$, regardless of the temperature level, but its production tends to rise at the optimum temperature, between 25 and $30^{\circ} \mathrm{C}$ in $A$. ochraceus [7].

Among the OTA-producing Aspergillus species, most of them belong to two sections: Circumdati (A. ochraceus group) and Nigri (A. carbonarius and A. niger) [8]. Earlier, A. ochraceus was considered to be the main source for OTA production in relatively warmer regions, while $P$. verrucosum being in colder areas [9]. However, A. westerdijkiae, a potential OTA producing fungus that is phylogenetically similar to A. ochraceus, is frequently found in tropical regions, and although it does not grow at $37^{\circ} \mathrm{C}$, it is still considered to be one of the important OTA producers [10].

Varga et al. detected OTA production in different Aspergillus species, i.e., A. alliaceus, A. sclerotiorum, A. sulphureus, A. albertensis, A. auricomus, and A. wentii [11]. Among them, A. alliaceus is an important OTA producing fungus contaminating figs in California [12]. Reports by Rizzo et al. indicated that other species of Aspergillus, such as A. auricomus, A. fumigates, A. versicolor, A. albertensis and A. wentii, could also produce OTA [13]. Another study reported the production of OTA by $A$. niger, A. lacticoffeatus and A. sclerotioniger [14]. A. cretensis, A. flocculosus, A. pseudoelegans, A. roseoglobulosus, A. westerdijkiae, A. sulphurous, and Neopetromyces muricatus are consistently reported to be the large producers of OTA [10]. A. steynii, which contaminates coffee, appeared to be an OTA producer $[15,16]$. A. welwitschiae (formerly A. awamori) was also confirmed as an OTA producer [17,18]. Recently, in submerge driparian decomposing leaves, a new OTA producing fungus was identified, A. affinis [19].

OTA-producing Penicillium species like P. verrucosum, P. nordicum and P. expansum, have been isolated and identified $[8,20]$. P. nordicum generally contaminates food rich in $\mathrm{NaCl}$ and protein, such as cheeses and dry cured meats, while $P$. verrucosum usually contaminates cereals and is occasionally found on dry cured ham and brined olives [21]. Other Penicillium species, P. chrysogenum, $P$. glycyrrhizacola and P. polonicum, were able to synthesize OTA on fresh or dry liquorice where P. chrysogenum was a high OTA producer [22]. Some Penicillium species like P. brevicompactum, P. crustosum, P. olsonii and P. oxalicum produced much lower levels of OTA, less than $0.1 \mathrm{ppb}$ [23]. The only well ascertained OTA producers in Penicillium genus are P. verrucosum and P. nordicum, although there are many reports on other OTA-producing Penicillium species as others may erroneously be claimed to be OTA producers or are sometimes erroneously identified. 
Table 1. Ochratoxin A production mainly by Aspergillus and Penicillium species.

\begin{tabular}{|c|c|c|c|c|c|}
\hline Number & Organism/Name & SubGroup & Section & Location & Source \\
\hline 1 & Aspergillus affinis & Ascomycetes & Circumdati & Italy & decomposingleaves, fluvial mycobiota \\
\hline 2 & Aspergillus albertensis & Ascomycetes & Flavi & Canada & ear swab \\
\hline 3 & Aspergillus alliaceus & Ascomycetes & Flavi & USA, Australia, Indonesia & macrobasis albida, great barrier reef, kemiri nut, soil \\
\hline 4 & Aspergillus welwitschiae & Ascomycetes & Nigri & Japan, Portugal, Spain, Italy, Greece & koji, Grapes \\
\hline 5 & Aspergillus carbonarius & Ascomycetes & Nigri & China, Italy, Australia, USA & grape, beer, coffee \\
\hline 6 & Aspergillus cretensis & Ascomycetes & Circumdati & Greece, Israel & citrus, soil \\
\hline 7 & Aspergillus flocculosus & Ascomycetes & Circumdati & Slovenia, India, Netherlands, Greece & saltern \\
\hline 8 & Aspergillus lacticoffeatus & Ascomycetes & Nigri & Venezuela, Indonesia & coffee bean, soil \\
\hline 9 & Aspergillus niger & Ascomycetes & Nigri & China, Italy, Spain, Germany, USA & grape, beer, cereal, coffee, triticum aestivum, zeamays \\
\hline 10 & Aspergillus ochraceus & Ascomycetes & Circumdati & $\begin{array}{l}\text { China, Italy, Portugal, Denmark, UK, } \\
\text { Japan, France }\end{array}$ & cereal, coffee, beverage, grape, zeamays \\
\hline 11 & Aspergillus pseudoelegans & Ascomycetes & Circumdati & Costa Rica & soil \\
\hline 12 & Aspergillus roseoglobulosus & Ascomycetes & Circumdati & Bahamas & decaying leave of rhizophora mangle \\
\hline 13 & Aspergillus sclerotioniger & Ascomycetes & Nigri & India & coffee bean, green coffee \\
\hline 14 & Aspergillus sclerotiorum & Ascomycetes & Circumdati & USA, Thailand, China & malus sylvestris, fruit, soil \\
\hline 15 & Aspergillus steynii & Ascomycetes & Circumdati & $\begin{array}{l}\text { India, China, Australia, Panama, } \\
\text { Argentina, Sri Lanka }\end{array}$ & green coffee bean, rice, arecha catechu, soybean \\
\hline 16 & Aspergillus sulphureus & Ascomycetes & Circumdati & India, China & alkaline soil \\
\hline 17 & Aspergillus westerdijkiae & Ascomycetes & Circumdati & South Africa, China, Slovenia, India & $\begin{array}{l}\text { rice, beverage, green coffee bean, saltern, sorghum, } \\
\text { corn, chili, anise, grapes }\end{array}$ \\
\hline 18 & Neopetromyces muricatus & Ascomycetes & - & Australia, Philippines, Indonesia & peanut, soil \\
\hline 20 & Penicillium nordicum & Ascomycetes & - & Germany, Italy & cheese, fermented meats \\
\hline 21 & Penicillium verrucosum & Ascomycetes & - & Germany, Australia, Italy, UK, Sweden & cereal, grape, triticum durum, rye, barely \\
\hline
\end{tabular}




\section{Ochratoxin A Biosynthetic Pathway}

\subsection{OTA Related Metabolites}

L-Phenylalanine was recognized a precursor of OTA by radiolabeling experiments where $1-{ }^{14} \mathrm{C}$-phenylalanine was incorporated into the phenylalanine moiety when supplied in the culture of A. ochraceus $[1,24]$. The isocoumarin moiety of OTA was mostly derived via acetate condensation with the addition of $2-{ }^{14} \mathrm{C}-\mathrm{Na}$-acetate.

The biosynthesis of ${ }^{14} \mathrm{C}$-labeled OTA was carried out in the liquid culture of $P$. verrucosum sp. 1761 using $2-{ }^{14} \mathrm{C}-\mathrm{Na}$-acetate and $2-{ }^{14} \mathrm{C}$-malonic acid as precursors and they were both found to be incorporated in OTA biosynthesis [25]. Furthermore, the whole molecular structure of OTA was labeled with $2-{ }^{14} \mathrm{C}-\mathrm{Na}$-acetate as precursor. However, the isocoumarin moiety of OTA was exclusively labeled by $2-{ }^{14} \mathrm{C}$-malonic acid, indicating that both acetate and malonic acid are the precursors of OTA biosynthesis. Malonic acid could be involved in the isocoumarin moiety biosynthesis but not the phenylalanine moiety biosynthesis, whereas acetate was transformed to both the phenylalanine moiety and the isocoumarin portion as a precursor.

${ }^{14} \mathrm{C}$-labeled precursor feeding experiments demonstrated that the carboxyl carbon of the amide group was derived from methionine at C-7 in the isocoumarin moiety of OTA [24]. The methylation inhibitor ethionine completely inhibited OTA production [26], which further confirmed that methionine was the substrate as the donor of carboxyl carbon at C-7 of the isocoumarin moiety. Ochratoxin $\alpha$ $(\mathrm{OT} \alpha)$ was the dihydroisocoumarin derivative with a carboxyl group at C-7. OTA was synthesized by the linking bond between OT $\alpha$ and phenylalanine by a crude cell-free enzyme preparation [27]. Corresponding des-chloro analogues were identified as ochratoxins B (OTB) and ochratoxin $\beta$ (OT $\beta$ ) [28]. OT $\beta$ and mellein had been isolated from ochratoxinogenic $A$. ochraceus cultures $[29,30]$, while OT $\alpha$ was not detected in OTA related intermediate at the beginning of $A$. ochraceus growth, which was actually obtained by acid hydrolysis of OTA [24,31-33]. However, Gallo et al. reported that OT $\alpha$ could be detected in liquid cultures of $A$. carbonarius ITEM 5010 analyzed by HPLC-FLD and HPLC-HRMS [34]. The incorporation of ${ }^{36} \mathrm{Cl}$ into the isocoumarin moiety of OTA was demonstrated by Wei et al. [35].

Mellein and 4-hydroxymellein could be produced and isolated by an OTA-producing strain of A. ochraceus [29]. Their structures are similar to the dihydroisocoumarin portion of ochratoxin A and B. The lactoneacids from ochratoxin A and B were structurally related to mellein and probably related to mellein genetically [2].

\subsection{OTA Biosynthesis Genes}

\subsubsection{Polyketide Synthase (PKS) and Non-Ribosomal Peptide Synthetase (NRPS)}

PKS and NRPS are large multimodular enzymes involved in biosynthesis of polyketide and peptide products as secondary metabolites, respectively [36]. From the structure of OTA, its dihydrocoumarin moiety consists of a polyketide that is believed to be catalyzed by PKS. The polyketide moiety is linked with L-phenylalanine through the carboxyl group catalyzed by a peptide synthase, generally NRPS [37]. The hybrid PKS-NRPS occurs frequently in the production of secondary metabolites [36].

Analysis of differentially expressed genes was carried out under different conditions that were either suitable for OTA production or not by Differential Display Reverse Transcriptase-PCR (DDRT-PCR) [38,39]. The differentially expressed genes contained putative genes encoding PKS, NRPS and halogenase involved in OTA biosynthesis [39]. A putative gene cluster was then identified in P. nordicum, which was responsible for OTA biosynthesis [40-42]. A polyketide synthase (otapksPN) and a non-ribosomal peptide synthetase $(n p s P N)$ were putatively involved in OTA biosynthetic pathway $[40,41]$. This was further confirmed at gene transcriptional level under OTA producing conditions and the mutant analysis via gene inactivation. Interestingly, the $p k s$ and $n r p s$ homolog genes 
could have not been identified in ochratoxigenic Aspergillus species. This indicates that the ochratoxin PKS and NRPS might be genus specific between Penicillium and Aspergillus species.

From then on, pks genes required for OTA biosynthesis were, respectively, identified by gene inactivation and OTA analysis in A. ochraceus [43], A. westerdijkiae [44], A. carbonarius [45] and P. verrucosum [46]. A pks gene, AcOTApks, involved in OTA biosynthesis was identified and recognized to play a critical role in the OTA biosynthesis in A. carbonarius, and then it was further confirmed that a nrps gene, located closer to the $p k s$, played an important role in OTA biosynthesis by the nrps deletion with no OTA production [34]. The amino acid sequences of these PKS and NRPS showed high similarity, compared to the predicted OTA gene cluster in A. niger CBS513.88 [47].

\subsubsection{Halogenase and P450 Oxidase}

Geisen et al. identified the putative gene cluster responsible for the OTA biosynthesis and among these genes in this cluster, there is an open reading frame encoding a putative OTA biosynthetic protein homologous to a halogenase/chloroperoxidase responsible for the introduction of the chlorine atom by a chlorination step in OTA biosynthetic pathway [39,42].

Actually, it is also demonstrated that an oxidase may play an important role in the step of oxidized reaction during the biosynthetic process of the final polyketide precursor. A gene encoding a cytochrome P450 family protein was identified by analyzing differentially expressed genes between ochratoxin-producing and non-producing strains of $A$. westerdijkiae [48]. Among differentially expressed genes, three putative oxidoreductase genes were highly up-regulated in the OTA producing strain compared to non-producing strain.

\subsection{Putative OTA Biosynthetic Pathway}

Although OTA is a very important mycotoxin for food security and human health, the genetic background of OTA biosynthesis is little known compared to the other important mycotoxins such as aflatoxins, fumonisins and zearalenones [37].

It was likely considered that the biosynthesis of the lactone acids part of ochratoxin A and B were derived from head-to-tail condensation of five acetate (or one acetate and four malonate) units by an analogy of the biosynthesis of citrinine in A. candidus [49] and oospolactone in Oosporu ustringenes [50] according to Steyn and Holzapfel [24].

OTA biosynthetic pathway had been proposed as a scheme by Huff and Hamilton [51]. They hypothesized that mellein, catalyzed by PKS, was oxidized to OT $\beta$ and then transformed to OT $\alpha$ by a halogenase/chloroperoxidase. Subsequently, OT $\alpha$ was esterified to ochratoxin C via link with the ethyl ester, and finally biosynthesized to OTA by a deesterification reaction.

However, they ignored the putatively ubiquitous intermediate, OTB, in some processes of OTA biosynthetic pathway. During the study on $p k s$ gene involved in OTA biosynthesis in A. westerdijkiae NRRL 3174, it was found that mellein played no role in OTA biosynthesis on analyzing the secondary metabolites [44,52]. This was further supported by ${ }^{14} \mathrm{C}$-labelled precursor feeding experiments, which did not support the intermediary role of mellein confirmed by Harris and Mantle [31]. On the other hand, the ester ochratoxin C, proposed to protect the phenylalanine carboxyl by Huff and Hamilton during the last OTA biosynthetic step [51], was found to have no role as the intermediate. In Harris and Mantle's study, they proposed that OT $\beta$ to OT $\alpha$ is catalyzed by a halogenase/chloroperoxidase and eventually to OTA via an amide bond with phenylalanine [31]. Chlorination of OT $\alpha$ probably preceded the biotransformation from OT $\alpha$ to OTA. This indicated that chlorination was a penultimate biosynthetic step in OTA biosynthesis. Moreover, they proposed an alternative pathway on account of the role of OTB in which OTA was transformed through the synthetic step from OT $\beta$ to OTB via an amide group, but this did not explain the role of OT $\alpha$ involvement in OTA biosynthesis. It seems to support that OTB was not a byproduct of OTA because the levels of OTA and OTB produced by A. ochraceus differed from one carbon or nitrogen source to another [53]. If this view were considered 
correct, both OTA and OTB would be affected and changed in a similar way as expected by the different nutrition conditions.

Similarly, ochratoxin C was not considered to be involved in OTA biosynthesis by Gallo et al. as it was not detected in A. carbonarius liquid culture [34]. They represented a novel OTA biosynthetic pathway similar to the alternative pathway of Harris and Mantle, i.e., OT $\beta$ to OTB by NRPS, and then to OTA by a halogenase/chloroperoxidase. However, OT $\alpha$ was mostly likely to be derived from the biodegradation activity in A. carbonarius ITEM 5010, because OTA was quickly and completely biotransformed and accordingly OT $\alpha$ was accumulated at a similar time during the culture of A. carbonarius, by adding with exogenous OTA in the mutant of nrps gene disruption. This might be a self-protection strategy in this fungus.

\section{Regulation Mechanisms of Ochratoxin A Biosynthesis}

\subsection{Specific Regulators of OTA Pathway}

Generally, among mycotoxins gene cluster, there exists one or more regulatory genes controlling the expression of biosynthetic genes. In aflatoxin biosynthetic gene cluster, aflR positively regulated aflatoxin and sterigmatocystin synthesis by binding to the promoter region of all the biosynthetic genes except aflJ and activating their transcription $[54,55]$. The gene cluster of fumonisin biosynthesis also contains a transcription factor, FUM21, predicted to be a Zn(II)-2Cys6 DNA-binding protein [56]. FUM21 positively activates FUM gene transcription and plays an important role in fumonisin biosynthesis. Among the zearalenone biosynthetic cluster genes, ZEB2 encode a transcriptional factor and expressed two isoforms (ZEB2L and ZEB2S) via an alternative promoter in F. graminearum [57]. ZEB2L, a basic leucinezipper (bZIP) DNA-binding domain at the $\mathrm{N}$-terminus included, interacts with ZEB2S, lacking the bZIP domain, to generate a formation of a heterodimer that regulates zearalenone biosynthesis. Among Tri genes in trichothecene biosynthetic gene cluster, two Tri genes, Tri6 and Tri10, regulate T-2 toxin production [58]. Tri10 inactivation could inhibit T-2 biosynthesis which markedly decreased the expression profile of all other Tri genes $[59,60]$. Tri6, encoding a $\mathrm{Cys}_{2} \mathrm{His}_{2}$ zinc finger transcription factor, was involved in T-2 production by positively regulating the transcription levels of Tri5 and Tri4 [61] and so was the putative patulin regulatory gene pat $L$ in patulin biosynthetic gene cluster controlling patulin production [62]. Overall, one or more biosynthetic pathway-specific regulators are located in many mycotoxin biosynthetic gene clusters, control the expression of their biosynthetic genes and affect the respective mycotoxin production. Therefore, there may be a pathway-specific regulatory gene controlling OTA production by regulation the expression profile of OTA biosynthetic genes.

A putative $p k s$ gene aolc35-12 could code for a certain polyketide compound complementary for the expression of aoks1, which might be required for OTA biosynthesis in A. westerdijkiae NRRL 3174 [44], which activated OTA biosynthesis in A. westerdijkiae [52]. The inner mechanisms have not yet been confirmed whether the polyketide product could play the complementary role for the $p k s$ gene to involve in OTA biosynthesis. Similarly, AcOTApks, characterized as a component of the OTA biosynthetic pathway [45], showed difference from an ACpks protein suggesting its likely involvement in OTA biosynthesis in A. carbonarius [63]. There also exists two PKSs involved in OTA biosynthesis likely by different manners [43]. Interestingly, for some instances that other secondary metabolites in fungi likely requiring two PKSs for a polyketide production, such as asperfuranone in A. nidulans [64], zearalenone in Gibberella zeae [65,66], T-toxin in Cochliobolus heterostrophus [67], compactin in Penicillium citrinum [68], and lovastatin in A. terreus [69,70]. However, the mechanisms of these two different PKSs that are likely responsible for OTA biosynthesis still remain to be established in future. 


\subsection{General Regulatory Pathways for OTA Biosynthesis}

\subsubsection{Velvet Complex Controls OTA Production}

It was identified that the heterotrimeric velvet complex, VelB/VeA/LaeA, could coordinate fungal development with secondary metabolism in A. nidulans, in response to light [71]. Among velvet complex, VeA subcellular localization depends on light [72]. Interestingly, light is a critical influence on growth and OTA production. Conidia formation, mycelial growth and OTA production could be affected by white and UV light treatment in A. ochraceus [73]. The inhibitory effects were strongest on growth and OTA production under red (long wavelength at $627 \mathrm{~nm}$ ) and blue (short wavelength at 470-455 nm) light condition [74]. Fanelli et al. had similar results on growth, conidiation and OTA biosynthesis under the influence of light in A. niger [75]. Furthermore, VeA and LaeA transcriptional factors were studied via gene replacement strategy and found that inactivation of $v e A$ and lae $A$ showed slighter differences in vegetative growth but a marked reduction in conidial production in A. carbonarius [76]. It was revealed that OTA production was promoted in A. carbonarius under dark conditions, whereas conidiation was activated with light treatment. OTA and conidial production was drastically decreased in $\Delta v e A$ or $\triangle l a e A$ null mutants. VeA was reported to be mainly located in the cytoplasm in response to light, while in the dark VeA was migrated into the cell nucleus in A. nidulans [72]. A putative nuclear localization signal (NLS) motif in the VeA amino acid sequence played an important role in the migration of VeA from the cytoplasm to the nucleus in A. nidulans. Accordingly, NLS motif was found in the N-terminal region of VeA in A. carbonarius putatively required for VeA to enter into the nuclei [76]. LaeA was reported to act chromatin-based regulation of secondary metabolites by modifications of histones acetylation [77]. Hence, it might be shown that VeA could be transported to the nucleus and interacted with LaeA under dark condition in $A$. carbonarius [76]. In this study, transcription level of veA and laeA was relatively similar in $A$. carbonarius in response to both light and dark, which led to the prediction that the subcellular localization of VeA was critical to the regulation of OTA production under light treatment, rather than the transcription level of the regulators [76]. Moreover, VeA and LaeA regulation might function at multiple layers of regulation network, such as transcription, post-transcriptional processing, translation, or posttranslational modification.

\subsubsection{Oxidative Stress}

The correct redox balance is one of the most crucial factors for the regulation of the growth, conidial formation, and secondary metabolite biosynthesis in fungi. There are inner correlations between the modulation of oxidative stress and mycotoxin biosynthesis, such OTA or aflatoxin modulated by oxidative stress related transcription factor, Yap1 [78,79]. Reverberi et al. revealed that OTA production was highly correlated with lipoperoxidation. The inactivation of a lipoxygenase (LOX) gene (AoloxA) displayed different phenotype on colony morphology, conidia formation, and sclerotia production, a lower LOX activity, the diminished level of some oxylipins derived from linoleic acid, and remarkably inhibited OTA production in A. ochraceus [80]. To investigate the role of oxidative stress related transcription factors in regulating mycotoxin production and reactive oxygen species (ROS) produced under oxidative stress condition, they studied the role of oxidative stress related transcription factor, Aoyap1, a homolog of the Yap-1 from yeast correspondingly [79]. The Aoyap1 disrupted strain could not scavenge ROS efficiently as it remained at high level, which was proposed to be associated with the reduced activity of superoxide dismutases and catalases in that their gene expressions were obviously decreased overall in $\Delta$ Aoyap1, compared to the wild type. Moreover, the conidia formation was significantly reduced and the conidia tend to be larger in solid media in the mutant. Its growth was also reduced and delayed in $\Delta \mathrm{Aoyap} 1$ in response to $\mathrm{CCl}_{4}$. Interestingly, Geisen et al. reported that high oxidative stress conditions led to the changes of secondary metabolites from OTA to citrinin and there existed the cross-regulation of the ochratoxin A/citrinin in response to different environment factors [81]. In addition, Stoll et al. studied the differentially expressed proteins 
of $P$. verrucosum under light of short wavelength $(450 \mathrm{~nm})$ or in the dark using comparative proteome analysis and found that most of these proteins (light $v s$. dark) are assumed to be related to stress and general metabolic processes in the 46 significantly differential proteins identified. The OTA production is strongly reduced under light of short wavelength as the induction of stress-related proteins could efficiently normalize oxidative stress although light of short wavelength could lead to oxidative stress

\subsection{3. $\mathrm{pH}$ Regulates OTA Biosynthesis via PacC}

External $\mathrm{pH}$ is regarded as a critical element to affect the growth, the development and secondary metabolites biosynthesis of fungi. Molds must adapt to their $\mathrm{pH}$ surroundings for their growth and reproduction. Many fungi can grow well in a broader $\mathrm{pH}$ range and the expression of certain genes are bound to the environmental $\mathrm{pH}$ [82]. Gene expression is efficiently regulated by transcriptional factors like PacC to produce several secondary metabolites by ambient $\mathrm{pH}$. PacC contains three zinc fingers motifs binding to the consensus sequence " 5 '-GCCARG" in the promoter region in $A$. nidulans [83,84]. The transcriptional factor PacC actively inhibits known acid-expressed gene expression and enables the expression of known alkaline-expressed genes in A. nidulans. PacC regulated aflatoxin and sterigmatocystin production in A. nidulans and A. Parasiticus, respectively [85]. Kapetanakou et al. evaluated the effect of OTA production with the combined environmental factors, $\mathrm{pH}$, water activity and temperature [86]. In their study, ambient $\mathrm{pH}$ seemed to have little specific effect compared to the influence of water activity for OTA biosynthesis in A. ochraceus and A. carbonarius. Esteban et al. found that OTA-producing $A$. niger not only adapted to a wider $\mathrm{pH}$ range for growth, but also produced OTA under a wider $\mathrm{pH}$ range [87]. Passamani et al. also reported that $A$. carbonarius and $A$. niger could grow and produce OTA well under a wider $\mathrm{pH}$ range [88]. They grew at the optimal condition with $\mathrm{pH}$ about between 5.0 and 6.5, and highest level of OTA production was observed at $\mathrm{pH}$ 5.35. Although several reviews have detailed the $\mathrm{pH}$ regulatory mechanism in A. nidulans [82,89-91], little is known about the cellular mechanisms of PacC regulating OTA production.

\subsubsection{Nutrient Sources on OTA Production via CreA and AreA}

Nutrients availability is generally regulated for adaption to environmental factors in fungi. Medina et al. found that OTA production was significantly different under various carbon sources in three isolates of Aspergillus spp. from grape and generally the correlation of the OTA level and the content of carbon sources was actually positive [92]. However, no marked difference in the OTA production with regard to nitrogen source except that phenylalanine seemed to be favorable for the toxin production. In the other report of Medina et al., they detected the capacity of OTA production using Yeast Extract Sucrose (YES) medium supplemented with 0.5\% peptone but found no significant differences [93]. Moreover, bee pollen was regarded as a strong stimulator for OTA production as a substrate in $A$. ochraceus. Furthermore, OTA level was positively related to the concentration of bee pollen adding to YES medium. On the contrary, in another study on the influence of carbon and nitrogen resources for OTA production in A. ochraceus, they indicated similar results that different carbon sources positively influence OTA production in MCB medium, and different carbon sources repressed OTA production in OTA permissive PDY medium except lactose, which showed high induction of OTA biosynthesis not only in MCB medium but also in PDY medium [53]. In addition, the inorganic nitrogen source, ammonium chloride, strongly reduced OTA level, while organic nitrogen sources promoted OTA production. Interestingly, OTA production showed positively correlation with carbon and nitrogen sources, except urea [94].

Carbon and nitrogen sources, as main nutrient sources, were regarded to be mediated by transcriptional factors. MIG1 was identified as a zinc finger protein involved in the repression of glucose-regulated genes [95]. CreA/Cre1 proteins, homologous to MIG1, have been described in A. nidulans [96], F. oxysporum [97], Gibberella fujikuroi [98], and Trichoderma reesei [99]. CreA binding site (-SYGGRG) was identified by DNase I footprinting in A. nidulans, which was further confirmed by deletion of the CreA binding sites resulting in derepression of prolineutilization cluster 
gene $[96,100]$. Nitrogen metabolism was defined and confirmed by the GATA transcription factor AreA in A. nidulans [101,102]. The regulation of nitrogen catabolism has been described in detail as a complex network with several transcriptional factors, AreA, NmrA and MeaB, in A. nidulans [102]. Therefore, the regulation of nutrient sources on OTA production needs in-depth study.

\subsubsection{Osmotic Stress}

Several signaling cascade pathways have been described as playing an important role for mycotoxin production by activating biosynthetic genes [71,82,103-105].

Increasing the amount of $\mathrm{NaCl}$, leading to high osmotic stress, it was assumed that a HOG-like cascade (high osmolarity glycerol) was incorporated with signal transduction [106]. The correlations between the growth and OTA production were evaluated in adaptation to different concentrations of $\mathrm{NaCl}$ in P. nordicum and P. verrucosum [21]. P. nordicum grew well and produced higher level of OTA under different $\mathrm{NaCl}$ concentrations as this fungus occurred mainly in dry cured meats or cheeses which are highly rich in $\mathrm{NaCl}[107,108]$. However, secondary metabolites shifted from citrinin to OTA in P. verrucosum by increasing concentrations of $\mathrm{NaCl}$. It was proposed that the induction of OTA production under $\mathrm{NaCl}$ condition was related to the phosphorylation status of the HOG-MAP kinase [109]. Conversely, OTA production was decreased with the increased $\mathrm{NaCl}$ concentrations, but the phosphorylation level of HOG was increased in A. carbonarius. In addition, the growth of this fungus was also remarkably repressed under this condition. However, less impact on the growth and phosphorylation of HOG were observed with respect to high glucose concentrations, although the toxin production decreased with the increasing glucose concentrations. Moreover, to confirm whether HOG was indeed necessary for OTA production under high osmolar stress, hog gene disruption was carried out in P. verrucosum and the results demonstrated the regulation of OTA biosynthesis by the HOG-MAP kinase. In addition, they analyzed the correlation between the growth rate, the level of HOG phosphorylation and the mycotoxin biosynthesis under different $\mathrm{NaCl}$ concentrations in $P$. verrucosum with different ability to produce the mycotoxin [110]. It was demonstrated that a weak OTA producer showed a poor growth rate and the strongest phosphorylation level of HOG1 protein from $0 \mathrm{~g} / \mathrm{L} \mathrm{NaCl}$ to $50 \mathrm{~g} / \mathrm{L}$. Although it appeared to confirm the correlation between HOG and OTA production, the reason why the differences exist among OTA-producing strains or non-producing strains under high osmotic stress and the question of whether the different mechanisms are involved in regulating OTA production with signal transduction need further investigation.

\section{Conclusions}

OTA has been successively studied for about half a century from the beginning of its isolation from A. ochraceus [1]. It has been realized that OTA is highly harmful for human heath due to its nephrotoxicity, hepatotoxicity, carcinogenicity, teratogenicity, and immunosuppression [2,111]. Studies have indicated several enzymes, such as PKS, NRPS, halogenase and P450 oxidase, that responsible for some steps of OTA biosynthesis. From OTA structure and biosynthetic genes of these enzymes, the OTA biosynthetic pathway has been putatively proposed [31,34,51], but still some contradictions appear exist. Accordingly, genetic regulation has also been investigated with regard to the interaction with environmental factors. Recently, genomic resources of OTA producing strains have been obtained and analyzed by genome-wide sequencing technologies, such as for $A$. niger CBS 513.88 and $A$. carbonarius ITEM5010 [45,47]. This will efficiently promote our understanding of the mechanisms of OTA production and regulation. Eventually, it will assist in developing effective strategies for protection food and feed from OTA contamination by understanding its biosynthesis and regulation.

Acknowledgments: This work was supported by the National Basic Research Program of China (973 program) (2013CB127805), the Special Fund for Agro-scientific Research in the Public Interest (201203037), and the National Program of China Basic Science and Technology Research (2013FY113400). 
Author Contributions: Yan Wang, Liuqing Wang and Yang Liu conceived and designed the review; Yan Wang and Liuqing Wang wrote the paper; Liuqing Wang, Fei Liu Jonathan Nimal Selvaraj, Fuguo Xing and Yueju Zhao contributed suggestions and revision of the paper.

Conflicts of Interest: The authors declare no conflict of interest.

\section{References}

1. Van der Merwe, K.J.; Steyn, P.S.; Fourie, L.; Scott, D.B.; Theron, J.J. Ochratoxin A, a toxic metabolite produced by Aspergillus ochraceus with. Nature 1965. [CrossRef]

2. El Khoury, A.; Atoui, A. Ochratoxin A: General overview and actual molecular status. Toxins 2010, 2, 461-493. [CrossRef] [PubMed]

3. Lea, T.; Steien, K.; Størmer, F.C. Mechanism of ochratoxin A-induced immunosuppression. Mycopathologia 1989, 107, 153-159. [CrossRef] [PubMed]

4. Pfohl-Leszkowicz, A.; Pinelli, E.; Bartsch, H.; Mohr, U.; Castegnaro, M. Sex- and strain-specific expression of cytochrome P450s in ochratoxin A-induced genotoxicity and carcinogenicity in rats. Mol. Carcinogenes. 1998, 23, 76-85. [CrossRef]

5. International Agency for Research on Cancer (IARC); World Health Organization (WHO). Some naturally occurring substances: Food items and constituents, heterocyclic aromatic aminesand mycotoxins. In IARC Monographs on the Evaluation of Carcinogenic Risks to Humans; IARC: Lyon, France, 1993; p. 56.

6. Commission, E. Commission regulation (EC) No. 1881/2006 of 19 december 2006 Setting maximum levels for certain contaminants in foodstuffs. Off. J. Eur. Union L 2006, I364, 4-5.

7. Futagami, T.; Mori, K.; Yamashita, A.; Wada, S.; Kajiwara, Y.; Takashita, H.; Omori, T.; Takegawa, K.; Tashiro, K.; Kuhara, S. Genome sequence of the white koji mold Aspergillus kawachiiIFO 4308, used for brewing the japanese distilled spirit shochu. Eukaryot. Cell 2011, 10, 1586-1587. [CrossRef] [PubMed]

8. Hayat, A.; Paniel, N.; Rhouati, A.; Marty, J.-L.; Barthelmebs, L. Recent advances in ochratoxin A-producing fungi detection based on PCR methods and ochratoxin A analysis in food matrices. Food Control 2012, 26, 401-415. [CrossRef]

9. Mantle, P.G. Risk assessment and the importance of ochratoxins. Int. Biodeterior. Biodegrad. 2002, 50, $143-146$. [CrossRef]

10. Frisvad, J.C.; Frank, J.M.; Houbraken, J.A.M.P.; Kuijpers, A.F.A.; Samson, R.A. New ochratoxin A producing species of Aspergillus section Circumdati. Stud. Mycol. 2004, 50, $23-43$.

11. Varga, J.; Kevei, E.; Rinyu, E.; Téren, J.; Kozakiewicz, Z. Ochratoxin production by Aspergillus species. Appl. Environ. Microbiol. 1996, 62, 4461-4464. [PubMed]

12. Paul, B.; Baker, J.L.; Doster, M.A.; Michailides, T.J.; Mahoney, N.E. Ochratoxin production by the Aspergillusochraceus group and Aspergillus alliaceus. Appl. Environ. Microbiol. 2002, 68, 2326-2329.

13. Rizzo, A.; Eskola, M.; Atroshi, F. Ochratoxin A in Cereals, Foodstuffs and Human Plasma. Europ. J. Plant Pathol. 2002, 108, 631-637. [CrossRef]

14. Robert, A.; Samson, J.A.M.P.H.; Angelina, F.A.; Kuijpers, J.; Frank, M.; Frisvad, J.C. New ochratoxin A or sclerotium producing species in Aspergillus section nigri. Stud. Mycol. 2004, 50, 45-61.

15. Gil-Serna, J.; Patiño, B.; Cortes, L.; Gonzalez-Jaen, M.T.; Vazquez, C. Aspergillus steynii and Aspergillus westerdijkiae as potential risk of OTA contamination in food products in warm climates. Food Microbiol. 2015, 46, 168-175. [CrossRef] [PubMed]

16. Gil-Serna, J.; Vázquez, C.; Sandino, F.G.; Valle, A.M.; González-Jaén, M.T.; Patiño, B. Evaluation of growth and ochratoxin A production by Aspergillus steynii and Aspergillus westerdijkiae in green-coffee based medium under different environmental conditions. Food Res. Int. 2014, 61, 127-131. [CrossRef]

17. Perrone, G.; Stea, G.; Epifani, F.; Varga, J.; Frisvad, J.C.; Samson, R.A. Aspergillus niger contains the cryptic phylogenetic species A. awamori. Fungal Biol. 2011, 115, 1138-1150. [CrossRef] [PubMed]

18. Seung-Beom, H.; Mina, L.; Dae-Ho, K.; Janos, V.; Frisvad, J.C.; Giancarlo, P.; Katsuya, G.; Osamu, Y.; Masayuki, M.; Jos, H. Aspergillus luchuensis, an industrially important black Aspergillus in east asia. PLoS ONE 2013, 8, e63769.

19. Davolos, D.; Pietrangeli, B. A molecular and bioinformatic study on the ochratoxin A (OTA)-producing Aspergillus affinis (section Circumdati). Mycotox Res. 2014, 30, 113-122. [CrossRef] [PubMed] 
20. Bogs, C.; Battilani, P.; Geisen, R. Development of a molecular detection and differentiation system for ochratoxin A producing penicillium species and its application to analyse the occurrence of Penicillium nordicum in cured meats. Int. J. Food Microbiol. 2006, 107, 39-47. [CrossRef] [PubMed]

21. Schmidt-Heydt, M.; Graf, E.; Stoll, D.; Geisen, R. The biosynthesis of ochratoxin A by Penicillium as one mechanism for adaptation to $\mathrm{NaCl}$ rich foods. Food Microbiol. 2012, 29, 233-241. [CrossRef] [PubMed]

22. Chen, A.J.; Tang, D.; Zhou, Y.Q.; Sun, B.D.; Li, X.J.; Wang, L.Z.; Gao, W.W. Identification of ochratoxin A producing fungi associated with fresh and dry liquorice. PLoS ONE 2013, 8, e78285. [CrossRef] [PubMed]

23. Vega, F.E.; Posada, F.; Peterson, S.W.; Gianfagna, T.J.; Chaves, F. Penicillium species endophytic in coffee plants and ochratoxin A production. Mycologia 2006, 98, 31-42. [CrossRef] [PubMed]

24. Steyn, P.S.; Holzapfel, C.W.; Ferreira, N.P. The biosynthesis of the ochratoxins, metabolites of Aspergillus ochraceus. Phytochemistry 1970, 9, 1977-1983. [CrossRef]

25. Ruhland, M.; Engelhardt, G.; Wallnöter, P.R. Production of ${ }^{14}$ C-ochratoxin a by Penicillium verrucosum sp. 1761 in liquid culture. Mycotox Res. 1996, 12, 7-13. [CrossRef] [PubMed]

26. Yamazaki, M.; Maebayashi, Y.; Miyaki, K. Biosynthesis of ochratoxin A. Tetrahedron Lett. 1971, 12, $2301-2303$. [CrossRef]

27. Ferreira, N.P.; Pitout, M.J. The biogenesis of ochratoxin. J. S. Afr. Chem. Inst. 1969, 22, S1-S8.

28. Steyn, P.S.; Holzapfel, C.W. The synthesis of ochratoxins A and B metabolites of Aspergillus ochraceus wilh. Tetrahedron 1967, 23, 4449-4461. [CrossRef]

29. Moore, J.H.; Davis, N.D.; Diener, U.L. Mellein and 4-hydroxymellein production by Aspergillus ochraceus wilhelm. Appl. Microbiol. 1972, 23, 1067-1072. [PubMed]

30. Delgadillo, I. Isolation of secondary metabolites of Aspergillus ochraceus by HPLC. Mycotox Res. 1986, 2, 9-17. [CrossRef] [PubMed]

31. Harris, J.P.; Mantle, P.G. Biosynthesis of ochratoxins by Aspergillus ochraceus. Phytochemistry 2001, 58, 709-716. [CrossRef]

32. Merwe, K.J.V.D.; Steyn, P.S.; Fourie, L. Mycotoxins. Part II. The constitution of ochratoxins A, B, and C, metabolites of Aspergillus ochraceus wilh. J. Chem. Soc. 1965, 7083-7088. [CrossRef]

33. Searcy, J.W.; Davis, N.D.; Diener, U.L. Biosynthesis of ochratoxin A. Appl. Microbiol. 1969, 18, 622-627. [PubMed]

34. Gallo, A.; Bruno, K.S.; Solfrizzo, M.; Perrone, G.; Mule, G.; Visconti, A.; Baker, S.E.; Gallo, A.; Bruno, K.S.; Solfrizzo, M.; et al. New insight into the ochratoxin A biosynthetic pathway through deletion of a nonribosomal peptide synthetase gene in Aspergillus carbonarius. Appl. Environ. Microbiol. 2012, 78, 8208-8218. [CrossRef] [PubMed]

35. Wei, R.D.; Strong, F.M.; Smalley, E.B. Incorporation of chlorine-36 into ochratoxin A. Appl. Microbiol. 1971, 22, 276-277. [PubMed]

36. Gallo, A.; Ferrara, M.; Perrone, G. Phylogenetic study of polyketide synthases and nonribosomal peptide synthetases involved in the biosynthesis of mycotoxins. Toxins 2013, 5, 717-742. [CrossRef] [PubMed]

37. Huffman, J.; Gerber, R.; Du, L. Recent advancements in the biosynthetic mechanisms for polyketide-derived mycotoxins. Biopolymers 2010, 93, 764-776. [CrossRef] [PubMed]

38. Farber, P.; Geisen, R. Investigation of ochratoxin A biosynthetic genes in Penicillium verrucosum by DDRT-PCR experiments: Differential expression of OTA genes. Mycotox Res. 2001, 17 (Suppl. 2), 150-155. [CrossRef] [PubMed]

39. Farber, P.; Geisen, R. Analysis of differentially-expressed ochratoxin A biosynthesis genes of Penicillium nordicum. Eur. J. Plant Pathol. 2004, 110, 661-669. [CrossRef]

40. Karolewiez, A.; Bogs, C.; Geisen, R. Genetic background of ochratoxin A production in Penicillium. Mycotox Res. 2005, 21, 46-48. [CrossRef] [PubMed]

41. Karolewiez, A.; Geisen, R. Cloning a part of the ochratoxin A biosynthetic gene cluster of Penicillium nordicum and characterization of the ochratoxin polyketide synthase gene. Syst. Appl. Microbiol. 2005, 28, 588-595. [CrossRef] [PubMed]

42. Geisen, R.; Schmidt-Heydt, M.; Karolewiez, A. A gene cluster of the ochratoxin A biosynthetic genes in Penicillium. Mycotox Res. 2006, 22, 134-141. [CrossRef] [PubMed]

43. Wang, L.; Wang, Y.; Wang, Q.; Liu, F.; Selvaraj, J.N.; Liu, L.; Xing, F.; Zhao, Y.; Zhou, L.; Liu, Y. Functional characterization of new polyketide synthase genes involved in ochratoxin A biosynthesis in Aspergillus ochraceus fc-1. Toxins 2015, 7, 2723-2738. [CrossRef] [PubMed] 
44. Bacha, N.; Atoui, A.; Mathieu, F.; Liboz, T.; Lebrihi, A.; Bacha, N.; Atoui, A.; Mathieu, F.; Liboz, T.; Lebrihi, A. Aspergillus westerdijkiae polyketide synthase gene "aoks1" is involved in the biosynthesis of ochratoxin A. Fungal Genet. Biol. 2009, 46, 77-84. [CrossRef] [PubMed]

45. Gallo, A.; Knox, B.P.; Bruno, K.S.; Solfrizzo, M.; Baker, S.E.; Perrone, G.; Gallo, A.; Knox, B.P.; Bruno, K.S.; Solfrizzo, M.; et al. Identification and characterization of the polyketide synthase involved in ochratoxin A biosynthesis in Aspergillus carbonarius. Int. J. Food Microbiol. 2014, 179, 10-17. [CrossRef] [PubMed]

46. Abbas, A.; Coghlan, A.; O'Callaghan, J.; Garcia-Estrada, C.; Martin, J.-F.; Dobson, A.D.W. Functional characterization of the polyketide synthase gene required for ochratoxin A biosynthesis in Penicillium verrucosum. Int. J. Food Microbiol. 2013, 162, 311. [CrossRef]

47. Pel, H.J.; de Winde, J.H.; Archer, D.B.; Dyer, P.S.; Hofmann, G.; Schaap, P.J.; Turner, G.; de Vries, R.P.; Albang, R.; Albermann, K.; et al. Genome sequencing and analysis of the versatile cell factory Aspergillus niger CBS 513.88. Nat. Biotechnol. 2007, 25, 221-231. [CrossRef] [PubMed]

48. Sartori, D.; Massi, F.P.; Ferranti, L.S.; Fungaro, M.H.P. Identification of genes differentially expressed between ochratoxin-producing and non-producing strains of Aspergillus westerdijkiae. Indian J. Microbiol. 2014, 54, 41-45. [CrossRef] [PubMed]

49. Birch, A.J.; Fitton, P.; Pride, E.; Ryan, A.J.; Smith, H.; Whalley, W.B. Studies in relation to biosynthesis. Part XVII. Sclerotiorin, citrinin, and citromycetin. J. Chem. Soc. 1958, 4576-4581. [CrossRef]

50. Nitta, K.; Yamamoto, Y.; Inoue, T.; Hyodo, T. Studies on the metabolic products of oospora astringenes. VII. Biogenesis of oospolactone and oosponol. Chem. Pharm. Bull. 1966, 14, 363-369. [CrossRef] [PubMed]

51. Huff, W.; Hamilton, P. Mycotoxins-their biosynthesis in fungi: Ochratoxins-metabolites of combined pathways. J. Food Prot. 1979, 42, 815-820.

52. Bacha, N.; Mathieu, F.; Liboz, T.; Lebrihi, A.; Bacha, N.; Mathieu, F.; Liboz, T.; Lebrihi, A. Polyketide synthase gene aolc35-12 controls the differential expression of ochratoxin a gene aoks1 in Aspergillus westerdijkiae. World Mycotoxin J. 2012, 5, 177-186. [CrossRef]

53. Abbas, A.; Valez, H.; Dobson, A.D.W. Analysis of the effect of nutritional factors on OTA and OTB biosynthesis and polyketide synthase gene expression in Aspergillus ochraceus. Int. J. Food Microbiol. 2009, 135, 22-27. [CrossRef] [PubMed]

54. Payne, G.A.; Nystrom, G.J.; Bhatnagar, D.; Cleveland, T.E.; Woloshuk, C.P. Cloning of the afl-2 gene involved in aflatoxin biosynthesis from Aspergillus flavus. Appl. Environ. Microbiol. 1993, 59, 156-162. [PubMed]

55. Fernandes, M.; Keller, N.P.; Adams, T.H. Sequence-specific binding by Aspergillus nidulansAflR, a $\mathrm{C}_{6}$ zinc cluster protein regulating mycotoxin biosynthesis. Mol. Microbiol. 1998, 28, 1355-1365. [CrossRef] [PubMed]

56. Brown, D.; Butchko, R.M.; Proctor, R. The Fusarium verticillioides FUM gene cluster encodes a Zn(II)2Cys6 protein that affects FUM gene expression and fumonisin production. Eukaryot. Cell 2007, 6, 1210-1218. [CrossRef] [PubMed]

57. Park, A.R.; Son, H.; Min, K.; Park, J.; Goo, J.H.; Rhee, S.; Chae, S.K.; Lee, Y.W. Autoregulation of ZEB2 expression for zearalenone production in Fusarium graminearum. Mol. Microbiol. 2015, 97, 942-956. [CrossRef] [PubMed]

58. Merhej, J.; Richard-Forget, F.; Barreau, C. Regulation of trichothecene biosynthesis in Fusarium: Recent advances and new insights. Appl. Microbiol. Biotechnol. 2011, 91, 519-528. [CrossRef] [PubMed]

59. Peplow, A.W.; Tag, A.G.; Garifullina, G.F.; Beremand, M.N. Identification of new genes positively regulated by Tri10 and a regulatory network for trichothecene mycotoxin production. Appl. Environ. Microbiol. 2003, 69, 2731-2736. [CrossRef] [PubMed]

60. Tag, A.G.; Garifullina, G.F.; Peplow, A.W.; Ake, C.; Phillips, T.D.; Hohn, T.M.; Beremand, M.N. A novel regulatory gene, Tri10, controls trichothecene toxin production and gene expression. Appl. Environ. Microbiol. 2001, 67, 5294-5302. [CrossRef] [PubMed]

61. Proctor, R.H.; Hohn, T.M.; McCormick, S.P.; Desjardins, A.E. Tri6 encodes an unusual zinc finger protein involved in regulation of trichothecene biosynthesis in Fusarium sporotrichioides. Appl. Environ. Microbiol. 1995, 61, 1923-1930. [PubMed]

62. Tannous, J.; Khoury, R.E.; Snini, S.P.; Lippi, Y.; Khoury, A.E.; Atoui, A.; Lteif, R.; Oswald, I.P.; Puel, O. Sequencing, physical organization and kinetic expression of the patulin biosynthetic gene cluster from Penicillium expansum. Int. J. Food Microbiol. 2014, 189, 51-60. [CrossRef] [PubMed] 
63. Gallo, A.; Perrone, G.; Solfrizzo, M.; Epifani, F.; Abbas, A.; Dobson, A.D.W.; Mule, G. Characterisation of a pks gene which is expressed during ochratoxin A production by Aspergillus carbonarius. Int. J. Food Microbiol. 2009, 129, 8-15. [CrossRef] [PubMed]

64. Chiang, Y.-M.; Szewczyk, E.; Davidson, A.D.; Keller, N.; Oakley, B.R.; Wang, C.C.C. A gene cluster containing two fungal polyketide synthases encodes the biosynthetic pathway for a polyketide, asperfuranone, in Aspergillus nidulans. J. Am. Chem. Soc. 2009, 131, 2965-2970. [CrossRef] [PubMed]

65. Gaffoor, I.; Trail, F. Characterization of two polyketide synthase genes involved in zearalenone biosynthesis in Gibberella zeae. Appl. Environ. Microbiol. 2006, 72, 1793-1799. [CrossRef] [PubMed]

66. Kim, Y.T.; Lee, Y.R.; Jin, J.; Han, K.H.; Kim, H.; Kim, J.C.; Lee, T.; Yun, S.H.; Lee, Y.W. Two different polyketide synthase genes are required for synthesis of zearalenone in Gibberella zeae. Mol. Microbiol. 2005, 58, 1102-1113. [CrossRef] [PubMed]

67. Baker, S.E.; Kroken, S.; Inderbitzin, P.; Asvarak, T.; Li, B.-Y.; Shi, L.; Yoder, O.C.; Turgeon, B.G. Two polyketide synthase-encoding genes are required for biosynthesis of the polyketide virulence factor, T-toxin, by Cochliobolus heterostrophus. Mol. Plant-Microbe Interact. 2006, 19, 139-149. [CrossRef] [PubMed]

68. Abe, Y.; Suzuki, T.; Ono, C.; Iwamoto, K.; Hosobuchi, M.; Yoshikawa, H. Molecular cloning and characterization of an ML-236B (compactin) biosynthetic gene cluster in Penicillium citrinum. Mol. Genet. Genom. 2002, 267, 636-646. [CrossRef] [PubMed]

69. Kennedy, J.; Auclair, K.; Kendrew, S.G.; Park, C.; Vederas, J.C.; Richard Hutchinson, C. Modulation of polyketide synthase activity by accessory proteins during lovastatin biosynthesis. Science 1999, 284, 1368-1372. [CrossRef] [PubMed]

70. Hendrickson, L.; Davis, C.R.; Roach, C.; Nguyen, D.K.; Aldrich, T.; Mcada, P.C.; Reeves, C.D. Lovastatin biosynthesis in Aspergillus terreus: Characterization of blocked mutants, enzyme activities and a multifunctional polyketide synthase gene. Chem. Biol. 1999, 6, 429-439. [CrossRef]

71. Ozgür, B.; Sven, K.; Min, N.; Jin Woo, B.; Kerstin, H.; Oliver, V.; Susanna, B.-S.; Nak-Jung, K.; Nancy P, K.; Jae-Hyuk, Y. VelB/VeA/LaeA complex coordinates light signal with fungal development and secondary metabolism. Science 2008, 320, 1504-1056.

72. Stinnett, S.M.; Espeso, E.A.; Cobe09o, L.; Araújo-Bazán, L.; Calva, A.M. Aspergillus nidulansVeA subcellular localization is dependent on the importin alpha carrier and on light. Mol. Microbiol. 2007, 63, 242-255. [CrossRef] [PubMed]

73. Aziz, N.H.; Moussa, A.E. Influence of white light, near-UV irradiation and other environmental conditions on production of aflatoxin B-1 by Aspergillus flavus and ochratoxin A by Aspergillus ochraceus. Nahrung-Food 1997, 41, 150-154. [CrossRef]

74. Schmidt-Heydt, M.; Ruefer, C.; Raupp, F.; Bruchmann, A.; Perrone, G.; Geisen, R. Influence of light on food relevant fungi with emphasis on ochratoxin producing species. Int. J. Food Microbiol. 2011, 145, $229-237$. [CrossRef] [PubMed]

75. Fanelli, F.; Schmidt-Heydt, M.; Haidukowski, M.; Geisen, R.; Logrieco, A.; Mule, G. Influence of light on growth, conidiation and the mutual regulation of fumonisin B-2 and ochratoxin A biosynthesis by Aspergillus niger. World Mycotoxin J. 2012, 5, 169-176. [CrossRef]

76. Crespo-Sempere, A.; Marin, S.; Sanchis, V.; Ramos, A.J. VeA and LaeA transcriptional factors regulate ochratoxin A biosynthesis in Aspergillus carbonarius. Int. J. Food Microbiol. 2013, 166, 479-486. [CrossRef] [PubMed]

77. Shwab, E.K.; Bok, J.W.; Tribus, M.; Galehr, J.; Graessle, S.; Keller, N.P. Histone deacetylase activity regulates chemical diversity in Aspergillus. Eukaryot. Cell 2007, 6, 1656-1664. [CrossRef] [PubMed]

78. Reverberi, M.; Zjalic, S.; Punelli, F.; Ricelli, A.; Fabbri, A.A.; Fanelli, C. Apyap1 affects aflatoxin biosynthesis during Aspergillus parasiticus growth in maize seeds. Food Addit. Contam. 2007, 24, 1070-1075. [CrossRef] [PubMed]

79. Reverberi, M.; Gazzetti, K.; Punelli, F.; Scarpari, M.; Zjalic, S.; Ricelli, A.; Fabbri, A.A.; Fanelli, C. Aoyap1 regulates OTA synthesis by controlling cell redox balance in Aspergillus ochraceus. Appl. Microbiol. Biotechnol. 2012, 95, 1293-1304. [CrossRef] [PubMed]

80. Reverberi, M.; Punelli, F.; Scarpari, M.; Camera, E.; Zjalic, S.; Ricelli, A.; Fanelli, C.; Fabbri, A.A.; Reverberi, M.; Punelli, F.; et al. Lipoperoxidation affects ochratoxin A biosynthesis in Aspergillus ochraceus and its interaction with wheat seeds. Appl. Microbiol. Biotechnol. 2010, 85, 1935-1946. [CrossRef] [PubMed] 
81. Schmidt-Heydt, M.; Stoll, D.; Schütz, P.; Geisen, R. Oxidative stress induces the biosynthesis of citrinin by Penicillium verrucosum at the expense of ochratoxin. Int. J. Food Microbiol. 2015, 192, 1-6. [CrossRef] [PubMed]

82. Peñalva, M.A.; Joan, T.; Elaine, B.; Arst, H.N. Ambient pH gene regulation in fungi: Making connections. Trends Microbiol. 2008, 16, 291-300. [CrossRef] [PubMed]

83. Tilburn, J.; Sarkar, S.; Widdick, D.A.; Espeso, E.A.; Orejas, M.; Mungroo, J.; Peñalva, M.A.; Arst, H.N. The AspergillusPacC zinc finger transcription factor mediates regulation of both acid- and alkaline-expressed genes by ambient pH. EMBO J. 1995, 14, 779-790. [PubMed]

84. Espeso, E.A.; Tilburn, J.; Sánchez-Pulido, L.; Brown, C.V.; Valencia, A.; Arst, H.N.J.; Peñalva, M.A. Specific DNA recognition by the Aspergillus nidulans three zinc finger transcription factor PacC. J. Mol. Biol. 1997, 274, 466-480. [CrossRef] [PubMed]

85. Keller, N.P.; Nesbitt, C.; Sarr, B.; Phillips, T.D.; Burow, G.B. pH regulation of sterigmatocystin and aflatoxin biosynthesis in Aspergillus spp. Phytopathology 1997, 87, 643-648. [CrossRef] [PubMed]

86. Kapetanakou, A.E.; Panagou, E.Z.; Gialitaki, M.; Drosinos, E.H.; Skandamis, P.N. Evaluating the combined effect of water activity, $\mathrm{pH}$ and temperature on ochratoxin a production by Aspergillus ochraceus and Aspergillus carbonarius on culture medium and corinth raisins. Food Control 2009, 20, 725-732. [CrossRef]

87. Esteban, A.; Abarca, M.L.; Bragulat, M.R.; Cabañes, F.J. Effect of pH on ochratoxin A production by Aspergillus niger aggregate species. Food Addit. Contam. 2006, 23, 616-622. [CrossRef] [PubMed]

88. Passamani, F.R.; Hernandes, T.; Lopes, N.A.; Bastos, S.C.; Santiago, W.D.; Cardoso, M.D.G.; Batista, L.R. Effect of temperature, water activity, and $\mathrm{pH}$ on growth and production of ochratoxin A by Aspergillus niger and Aspergillus carbonarius from brazilian grapes. J. Food Prot. 2014, 77, 1947-1952. [CrossRef] [PubMed]

89. Arst, H.N.J.; Peñalva, M.A. pH regulation in Aspergillus and parallels with higher eukaryotic regulatory systems. Trends Genet. 2003, 19, 224-231. [CrossRef]

90. Peñalva, M.A.; Arst, H.N.J. Recent advances in the characterization of ambient $\mathrm{pH}$ regulation of gene expression in filamentous fungi and yeasts. Annu. Rev. Microbiol. 2004, 58, 425-451. [CrossRef] [PubMed]

91. Peñalva, M.A.; Arst, H.N., Jr. Regulation of gene expression by ambient $\mathrm{pH}$ in filamentous fungi and yeasts. Microbiol. Mol. Biol. Rev. 2002, 66, 426-446. [CrossRef] [PubMed]

92. Medina, A.; Mateo, E.M.; Valle-Algarra, F.M.; Mateo, F.; Mateo, R.; Jimenez, M. Influence of nitrogen and carbon sources on the production of ochratoxin A by ochratoxigenic strains of Aspergillus spp. isolated from grapes. Int. J. Food Microbiol. 2008, 122, 93-99. [CrossRef] [PubMed]

93. Medina, Á.; González, G.; Sáez, J.M.; Mateo, R.; Jiménez, M. Bee pollen, a substrate that stimulates ochratoxin A production by Aspergillus ochraceus wilh. Syst. Appl. Microbiol. 2004, 27, 261-267. [CrossRef] [PubMed]

94. Hashem, A.; Abd-Allah, E.F.; Al-Obeed, R.S.; Alqarawi, A.A.; Alwathnani, H.A. Effect of carbon, nitrogen sources and water activity on growth and ochratoxin production of Aspergillus carbonarius (bainier) thom. Jundishapur J. Microbiol. 2015, 8, e17569. [CrossRef] [PubMed]

95. Nehlin, J.O.; Ronne, H. Yeast MIG1 repressor is related to the mammalian early growth response and Wilms' tumour finger proteins. EMBO J. 1990, 9, 2891-2898. [PubMed]

96. Cubero, B.; Scazzocchio, C. Two different, adjacent and divergent zinc finger binding sites are necessary for CreA-meidiated carbon catabolite repression in the proline gene cluster of Aspergillus nidulans. EMBO J. 1994, 13, 407-415. [PubMed]

97. Wilfried, J.; Martijn, R. Mutation of Cre1 in Fusarium oxysporum reverts the pathogenicity defects of the FRP1 deletion mutant. Mol. Microbiol. 2009, 74, 1100-1113.

98. Tudzynski, B.; Liu, S.; Kelly, J.M. Carbon catabolite repression in plant pathogenic fungi: Isolation and characterization of the Gibberella fujikuroi and Botrytis cinereacreAgenes. FEMS Microbiol. Lett. 2000, 184, 9-15. [CrossRef] [PubMed]

99. Portnoy, T.; Margeot, A.; Linke, R.; Atanasova, L.; Fekete, E.; Sándor, E.; Hartl, L.; Karaffa, L.; Druzhinina, I.S.; Seiboth, B. The Cre1 carbon catabolite repressor of the fungus Trichoderma reesei: A master regulator of carbon assimilation. BMC Genom. 2011, 12, 1-12. [CrossRef] [PubMed]

100. Sophianopoulou, V.; Suárez, T.; Diallinas, G.; Scazzocchio, C. Operator derepressed mutations in the proline utilisation gene cluster of Aspergillus nidulans. Mol. Gen. Genet. MGG 1993, 236, 209-213. [CrossRef] [PubMed]

101. Wilson, R.A.; Arst, H.N. Mutational analysis of AreA, a transcriptional activator mediating nitrogen metabolite repression in Aspergillus nidulans and a member of the "streetwise" gata family of transcription factors. Microbiol. Mol. Biol. Rev. 1998, 62, 586-596. [PubMed] 
102. Wong, K.H.; Hynes, M.J.; Todd, R.B.; Davis, M.A. Transcriptional control of NmrA by the bZIP transcription factor MeaB reveals a new level of nitrogen regulation in Aspergillus nidulans. Mol. Microbiol. 2007, 66, 534-551. [CrossRef] [PubMed]

103. Garcia-Rico, R.O.; Mauriz, F.E. The heterotrimeric $G_{\alpha}$ protein Pga1 regulates biosynthesis of penicillin, chrysogenin and roquefortine in Penicillium chrysogenum. Microbiology 2008, 154, 3567-3578. [CrossRef] [PubMed]

104. Shwab, E.K.; Keller, N.P. Regulation of secondary metabolite production in filamentous ascomycetes. Mycol. Res. 2008, 112, 225-230. [CrossRef] [PubMed]

105. Moye-Rowley, W.S. Regulation of the transcriptional response to oxidative stress in fungi: Similarities and differences. Eukaryot. Cell 2003, 2, 381-389. [CrossRef] [PubMed]

106. Schmidt-Heydt, M.; Graf, E.; Batzler, J.; Geisen, R. The application of transcriptomics to understand the ecological reasons of ochratoxin a biosynthesis by penicillium nordicum on sodium chloride rich dry cured foods. Trends Food Sci. Technol. 2011, 22, S39-S48. [CrossRef]

107. Larsen, T.O.; Svendsen, A.; Smedsgaard, J. Biochemical characterization of ochratoxin A-producing strains of the genus Penicillium. Appl. Environ. Microbiol. 2001, 67, 3630-3635. [CrossRef] [PubMed]

108. Sonjak, S.; Ličen, M.; Frisvad, J.C.; Gunde-Cimerman, N. Salting of dry-cured meat-A potential cause of contamination with the ochratoxin A-producing species Penicillium nordicum. Food Microbiol. 2011, 28, 1111-1116. [CrossRef] [PubMed]

109. Stoll, D.; Schmidt-Heydt, M.; Geisen, R. Differences in the regulation of ochratoxin A by the HOG pathway in Penicillium and Aspergillus in response to high osmolar environments. Toxins 2013, 5, 1282-1298. [CrossRef] [PubMed]

110. Markus, S.H.; Stoll, D.A.; Jennifer, M.; Rolf, G. Intraspecific variability of HOG1 phosphorylation in Penicillium verrucosum reflects different adaptation levels to salt rich habitats. Int. J. Food Microbiol. 2013, 165, 246-250.

111. Petzinger, E.; Ziegler, K. Ochratoxin A from a toxicological perspective. J. Vet. Pharmacol. Ther. 2000, 23, 91-98. [CrossRef] [PubMed]

(C) 2016 by the authors; licensee MDPI, Basel, Switzerland. This article is an open access article distributed under the terms and conditions of the Creative Commons by Attribution (CC-BY) license (http://creativecommons.org/licenses/by/4.0/). 